\title{
Preparation and characterization of aluminum oxide nanoparticles by laser ablation in liquid as passivating and anti-reflection coating for silicon photodiodes
}

\author{
Raid A. Ismail $^{1} \cdot$ Shihab A. Zaidan ${ }^{1} \cdot$ Rafal M. Kadhim $^{1}$
}

Received: 1 July 2017/Accepted: 1 August 2017/Published online: 12 August 2017

(c) The Author(s) 2017. This article is an open access publication

\begin{abstract}
In this study, we have prepared aluminum oxide $\left(\mathrm{Al}_{2} \mathrm{O}_{3}\right.$ nanoparticles) NPs with size ranging from 50 to $90 \mathrm{~nm}$ by laser ablation of aluminum target in ethanol. The effect of laser fluence on the structural, morphological and optical properties of $\mathrm{Al}_{2} \mathrm{O}_{3}$ was demonstrated and discussed. X-ray diffraction XRD results confirm that the synthesized $\mathrm{Al}_{2} \mathrm{O}_{3} \mathrm{NPs}$ are crystalline in nature. The sample prepared at $3.5 \mathrm{~J} / \mathrm{cm}^{2} /$ pulse exhibits single phase of $\gamma-\mathrm{Al}_{2} \mathrm{O}_{3}$, while the XRD patterns of the nanoparticles synthesized at 5.3 and $7.5 \mathrm{~J} / \mathrm{cm}^{2} /$ pulse show the co-existence of the $\alpha-\mathrm{Al}_{2} \mathrm{O}_{3}$ and $\gamma-\mathrm{Al}_{2} \mathrm{O}_{3}$ phases. Nanostructured $\mathrm{Al}_{2} \mathrm{O}_{3}$ films have been used as anti-reflecting coating and surface passivation layer to improve the photoresponse characteristics of silicon photodiode. The experimental data showed that the optical energy gap decreases from 5.3 to $5 \mathrm{eV}$ as the laser fluence increases from 3.5 to $7.3 \mathrm{~J} / \mathrm{cm}^{2}$. The lowest optical reflectivity was found for silicon photodiode deposited with a single layer of $\mathrm{Al}_{2} \mathrm{O}_{3}$ prepared at $3.5 \mathrm{~J} / \mathrm{cm}^{2} /$ pulse. The effect of laser fluence on the refractive index and extinction coefficient of the nanostructured $\mathrm{Al}_{2} \mathrm{O}_{3}$ film was studied. The photosensitivity of the silicon photodiode increased from 0.4 to $1.4 \mathrm{AW}^{-1}$ at $800 \mathrm{~nm}$ after depositing $\mathrm{Al}_{2} \mathrm{O}_{3}$ prepared at $3.5 \mathrm{~J} / \mathrm{cm}^{2} /$ pulse, followed by rapid thermal annealing at $400{ }^{\circ} \mathrm{C}$ for $60 \mathrm{~s}$.
\end{abstract}

Keywords $\mathrm{Al}_{2} \mathrm{O}_{3} \cdot$ Nanoparticles $\cdot$ Laser ablation $\cdot$ Laser fluence $\cdot$ Ethanol $\cdot$ Silicon photodiode

Raid A. Ismail

raidismail@yahoo.com

1 Department of Applied Science, University of Technology, Baghdad, Iraq

\section{Introduction}

Metal oxide nanoparticles have drawn attention due to their stable optical, electrical and structural properties (Hart 1990, Noda and Muramoto 2003). Nanostructured aluminum oxide is the most important metal oxide material which is used widely in many industrial applications, such as catalyst, surface passivation, ant-reflection coating, sensors, gas diffusion barrier, abrasive materials and nanolaminates (Farsi and Gobal 2007; Tania et al. 1999; Dingemans and Kessels 2012; Groner et al. 2004; Tallarida et al. 2011 )Garces et al. 2014. $\mathrm{Al}_{2} \mathrm{O}_{3}$ is a wide band-gap $(\sim 6 \mathrm{eV}$ at $300 \mathrm{k}$ for bulk material) dielectric material which can exist in different crystalline forms such as gamma, delta, theta and alpha phases. Many techniques were used to prepare $\mathrm{Al}_{2} \mathrm{O}_{3}$ nanoparticles such as sol-gel (Mirjalili et al. 2010), sputtering (Trinh et al. 2008), spray (Kavitha and Jayaram 2006), hydrothermal (Qu et al. 2005), mechanical milling (Reid et al. 2008) and laser ablation (Yatsui et al. 2000). Synthesis of nanoparticles by pulsed laser ablation in liquid (PLAL) has many advantages compared to other conventional techniques: the produced nanoparticles are pure and have no impurities; the process does not need any complex agents; a large variety of materials may be synthesized; material stoichiometry is preserved; there is fair control on the size of the produced nanoparticles; the process is cost-effective and fast (Petersen and Barcikowski 2009; Yang et al. 2007). The reported data showed that the optical, structural and mechanical properties of $\mathrm{Al}_{2} \mathrm{O}_{3}$ nanoparticles prepared by PLAL depended on many parameters such as laser energy, laser wavelength, ablation time, laser pulse duration and liquid type (Piriyawong et al. 2012; Emmanue et al. 2009). $\mathrm{Al}_{2} \mathrm{O}_{3}$ layers have been used as anti-reflecting coating for silicon solar cells. Lee et al. (Benjamin et al. 2012) 


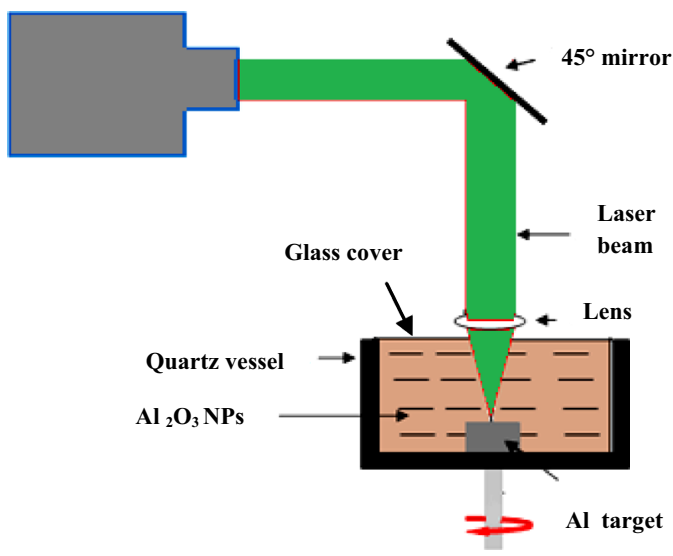

(a)

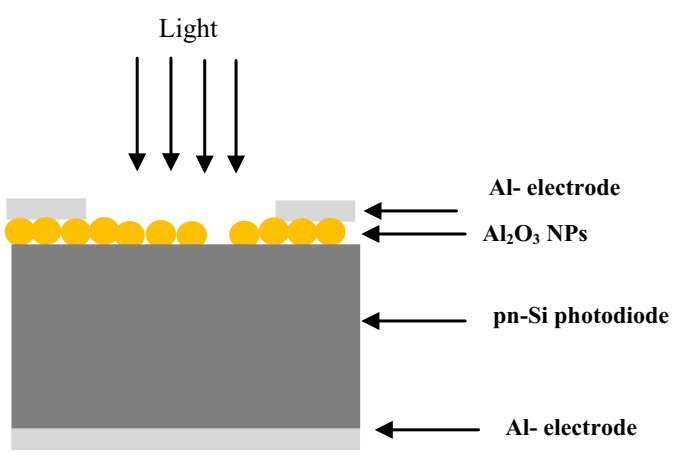

(b)

Fig. 1 Schematic diagram of the PLAL system used in this study (a) and the cross-sectional view of nanostructured $\mathrm{Al}_{2} \mathrm{O}_{3} / \mathrm{pn} \mathrm{Si}_{\mathrm{i}}$ photodiode

deposited $10 \mathrm{~nm} \mathrm{Al}_{2} \mathrm{O}_{3}$ as an anti-reflection coating layer on silicon solar cell using the atomic layer deposition (ALD) technique and showed that the cell efficiency increased after $\mathrm{Al}_{2} \mathrm{O}_{3}$ deposition. Leszek et al. (Leszek et al. 2014) showed that the difference in the silicon solar cells efficiency between that with and without $\mathrm{Al}_{2} \mathrm{O}_{3}$ antireflection coating was $5.28 \%$. Recently, Nguyen et al. (Huong et al. 2017) reported an increase in the efficiency of silicon solar cells from 17.55 to $18.34 \%$ after deposition of $\mathrm{Al}_{2} \mathrm{O}_{3} / \mathrm{a}-\mathrm{SiN}_{\mathrm{x}}: \mathrm{H}$, which acts as a surface passivation and anti-reflection coating layer. Here, we report the preparation and characterization of $\mathrm{Al}_{2} \mathrm{O}_{3}$ nanoparticles by laser ablation of aluminum target in ethanol at various laser fluences. The second objective of this study is to use the synthesized nanostructured $\mathrm{Al}_{2} \mathrm{O}_{3}$ film as anti-reflection and surface passivation coating to improve the performance of the silicon photodiode.

\section{Experimental}

In this experiment, a high purity aluminum target was placed at the bottom of a quartz vessel containing $2 \mathrm{~mL}$ of ethanol, irradiated by Nd:YAG laser pulses operated at $532 \mathrm{~nm}$ (frequency doubling) with a pulse duration of $7 \mathrm{~ns}$. To focus the laser beam on the Al target, a converging lens of $5 \mathrm{~cm}$ focal length was used as shown in Fig. 1a. The laser ablation process was performed at normal temperature with laser fluence varying from 3.5 to $7.5 \mathrm{~J} / \mathrm{cm}^{2} /$ pulse and the ablation time was maintained at $10 \mathrm{~min}$. The liquid was continuously stirred during laser irradiation using a regulated rotating motor. The optical absorption of colloidal aluminum oxide nanoparticles was measured using UV-Vis spectrophotometer with double beam (Shimadzu UV-1800). The structure of the synthesized nanoparticles was investigated using X-ray diffractometer (XRD-8000,
Shimadzu) using CuK $\alpha$ source $(\lambda=0.15419 \mathrm{~nm})$. To study the surface morphology of the $\mathrm{Al}_{2} \mathrm{O}_{3}$ nanoparticles, scanning electron microscopy SEM (Jeol JSM-6335F) and atomic force microscopy AFM (AA3000) were used. The shape and size of the $\mathrm{Al}_{2} \mathrm{O}_{3}$ nanoparticles were examined using transmission electron microscopy (type CM10 pw6020, Philips-Germany). The thickness and refractive index of the $\mathrm{Al}_{2} \mathrm{O}_{3}$ layer were measured using an ellipsometer. The $\mathrm{Al}_{2} \mathrm{O}_{3}$ layer of $100 \mathrm{~nm}$ thickness was deposited on $\mathrm{p}-\mathrm{n}$ silicon photodiode of $1 \mathrm{~cm}^{2}$ area by using the dip coating technique. The $\mathrm{p}-\mathrm{n}$ photodiode was fabricated by the Al-Mansour Iraqi factory using a standard thermally diffused route. After deposition of the $\mathrm{Al}_{2} \mathrm{O}_{3}$ film, ohmic contacts were established on both sides of the photodiode by depositing indium films using a thermal resistive technique. Fig. $1 \mathrm{~b}$ shows the schematic diagram of the silicon photodiode after deposition of $\mathrm{Al}_{2} \mathrm{O}_{3}$ film and ohmic contacts. The coated $\mathrm{p}-\mathrm{n}$ photodiode was annealed under a nitrogen atmosphere at $400{ }^{\circ} \mathrm{C}$ for $60 \mathrm{~s}$ with the aid of a rapid thermal annealing RTA system using halogen

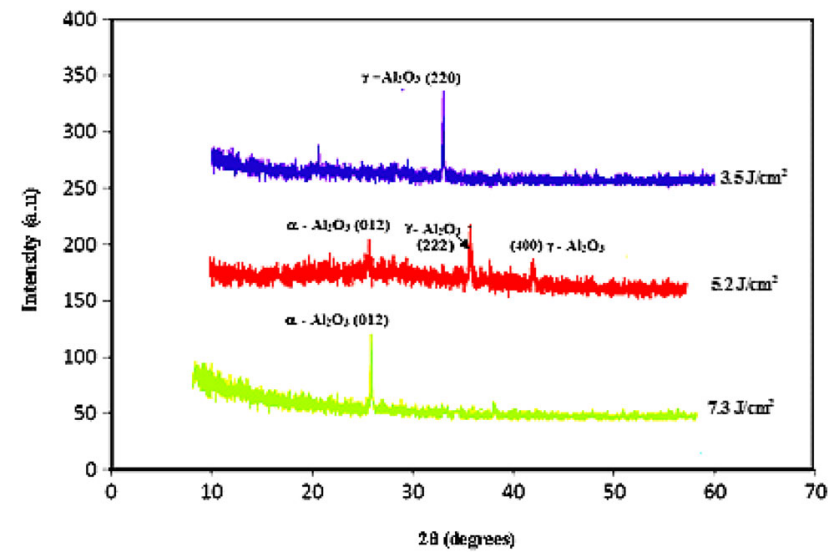

Fig. 2 XRD patterns of $\mathrm{Al}_{2} \mathrm{O}_{3}$ NPs deposited on glass substrate at various laser fluences 

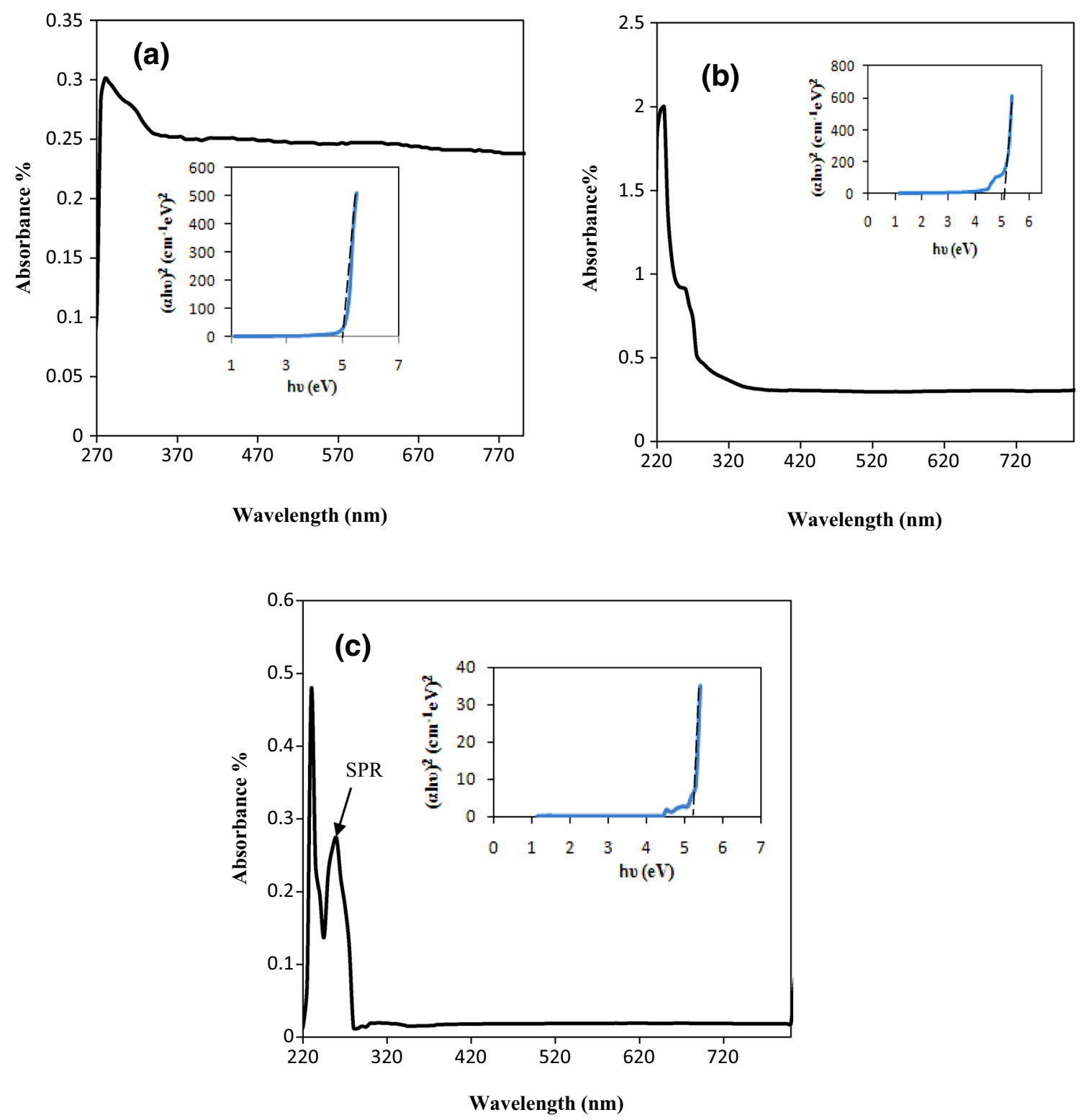

Fig. 3 Optical absorbance of fresh colloidal $\mathrm{Al}_{2} \mathrm{O}_{3}$ NPs prepared at different laser fluences: a $3.5 \mathrm{~J} / \mathrm{cm}^{2}$, b $5.2 \mathrm{~J} / \mathrm{cm}^{2}$, c $7.3 \mathrm{~J} / \mathrm{cm}^{2}$. Inset shows the $(\alpha h v)^{2}$ versus photon energy plot

lamps. The dark and illuminated current-voltage characteristics of coated $\mathrm{p}-\mathrm{n}$ photodiode were measured at different white light intensities. The spectral responsivity of coated photodiodes was investigated using a calibrated monochromator.

\section{Results and discussion}

Figure 2 shows the XRD patterns of $\mathrm{Al}_{2} \mathrm{O}_{3} \mathrm{NPs}$ prepared at different laser fluences. XRD pattern of alumina nanoparticles, prepared at $3.5 \mathrm{~J} / \mathrm{cm}^{2}$, exhibited a single diffraction peak located at $32^{\circ}$ corresponding to (220) plane which indexed to face centered cubic $\gamma-\mathrm{Al}_{2} \mathrm{O}_{3}$ metastable phase according to JCPD\# 29-0063, no peaks related to pure $\mathrm{Al}$ element or other metastable phases were found in XRD pattern indicating the complete transformation of $\mathrm{Al}$ into $\gamma-\mathrm{Al}_{2} \mathrm{O}_{3}$ after laser ablation. The XRD pattern confirms the co-existence of the $\gamma-\mathrm{Al}_{2} \mathrm{O}_{3}$ and $\alpha-\mathrm{Al}_{2} \mathrm{O}_{3}$ phases for nanoparticles prepared at $5.2 \mathrm{~J} / \mathrm{cm}^{2}$. The presence of these two phases can be ascribed to reaching the critical phase transition temperature after ablation with laser fluence of $5.2 \mathrm{~J} / \mathrm{cm}^{2}$. This interesting result needs further investigation. Complete phase transformation from the $\gamma-\mathrm{Al}_{2} \mathrm{O}_{3}$ phase to the $\alpha-\mathrm{Al}_{2} \mathrm{O}_{3}$ phase was noticed in the XRD pattern for alumina NPs 


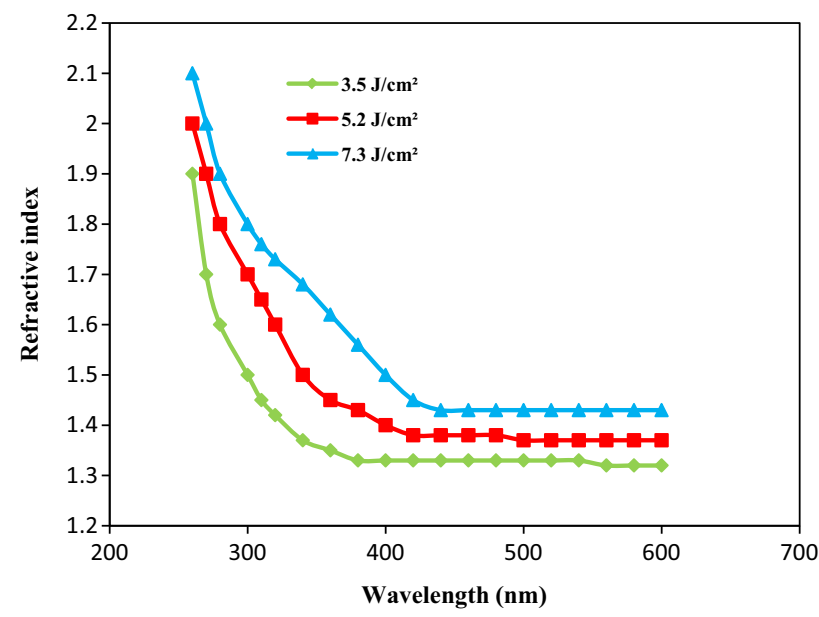

Fig. 4 Variation of refractive index with wavelength for $\mathrm{Al}_{2} \mathrm{O}_{3}$ prepared at various laser fluences

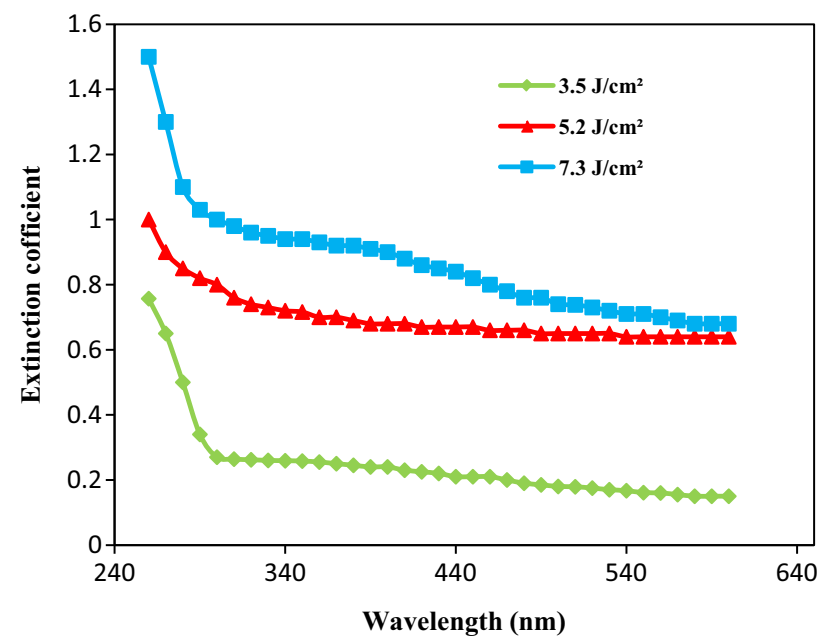

Fig. 5 Effect of laser fluence on the extinction coefficient for $\mathrm{Al}_{2} \mathrm{O}_{3}$ prepared at various laser fluences

synthesized at $7.3 \mathrm{~J} / \mathrm{cm}^{2}$. This result can be explained on the basis that increasing the laser fluence resulted in increasing the temperature, leading to the formation of a single $\alpha-\mathrm{Al}_{2} \mathrm{O}_{3}$ phase. As shown in the XRD pattern, the peak located at $26^{\circ}$ corresponding to the (012) plane is related to the rhombohedral stable $\alpha-\mathrm{Al}_{2} \mathrm{O}_{3}$ phase.

It is reported (Cava et al. 2007) that for nano powder alumina prepared by the polymeric precursor method, the alpha alumina phase could be formed by heat treatment at a temperature of $1050{ }^{\circ} \mathrm{C}$, while the gamma alumina phase formed at a temperature of around $900{ }^{\circ} \mathrm{C}$. The color of colloidal $\mathrm{Al}_{2} \mathrm{O}_{3}$ nanoparticles solution prepared at $3.5 \mathrm{~J} / \mathrm{cm}^{2}$ laser fluence and produce a light yellow transmission that changed to a dark color transmission after ablation with a higher laser fluence. The optical absorption spectra of $\mathrm{Al}_{2} \mathrm{O}_{3}$ NPs prepared at various laser fluences is shown in Fig. 3. The spectrum of colloidal $\mathrm{Al}_{2} \mathrm{O}_{3}$ prepared at a laser fluence of $3.5 \mathrm{~J} /$ $\mathrm{cm}^{2}$ exhibits a significant absorption peak at $255 \mathrm{~nm}$ (surface plasmon resonance SPR) due to the quantum size effect. The optical energy gap $E_{\mathrm{g}}$ has been determined from Tauc law for direct transition:

$\alpha h v=A\left(h v-E_{\mathrm{g}}\right)^{1 / 2}$,

where $\alpha$ is the absorption coefficient and $h v$ is the photon energy. By plotting $(\alpha h v)^{2}$ versus photon energy, the energy gap can be obtained by extrapolating the linear part to the $(h v=0)$ point, as shown in the inset of Fig. 3.The calculation shows that the optical band gap of alumina prepared at $3.5 \mathrm{~J} / \mathrm{cm}^{2}$ was found to be $5.4 \mathrm{eV}$; this value is lower than that of bulk alumina due to the presence of oxygen vacancies and point defects (Papi et al. 2015; Tamboli et al. 2011). An abrupt decrease in the optical absorption was observed at $\sim \lambda=280 \mathrm{~nm}$ and seemed to be steady after this wavelength (highly transparent). The optical absorption spectrum of $\mathrm{Al}_{2} \mathrm{O}_{3}$ prepared with $5.2 \mathrm{~J} /$ $\mathrm{cm}^{2}$ shows a small plasmon peak at $260 \mathrm{~nm}$, indicating the formation of nanosized alumina particles and the energy band gap was found to be around $5.15 \mathrm{eV}$ (as shown in Fig. $3 \mathrm{~b}$ ), which is about $0.25 \mathrm{eV}$ smaller than that prepared with lower laser fluence. On the other hand, it is clearly seen that the optical absorption is increased due to increase of the alumina concentration with laser fluence. Increasing the laser fluence to $7.3 \mathrm{~J} / \mathrm{cm}^{2}$ results in decreasing the optical energy gap due to increase of the particle size and maybe due to agglomeration of alumina particles (Khan et al. 2010; Julien et al. 2014). Furthermore, the phase transition and stoichiometry may also play a role in the variation of the energy gap of the metal oxide (Ismail et al. 2013). Figure 4 depicts the variation of refractive index with wavelength for nanostructured $\mathrm{Al}_{2} \mathrm{O}_{3}$. In general, the refractive index of all samples decreases as the wavelength increases and tends to be constant beyond $400 \mathrm{~nm}$, which is in good agreement with data reported by Shamala et al. (2004). The refractive index of $\mathrm{Al}_{2} \mathrm{O}_{3}$ was found to be dependent on the laser fluence. The refractive index decreases as laser fluence increases. Nanostructured $\mathrm{Al}_{2} \mathrm{O}_{3}$ prepared at $3.5 \mathrm{~J} / \mathrm{cm}^{2}$ has refractive index of 1.7 and 1.33 at 270 and $500 \mathrm{~nm}$, respectively. (Hua et al. 2014).

Increasing the laser fluence leads to increase in the refractive index which can be attributed to stoichiometry preservation and to the formation of high-density $\mathrm{Al}_{2} \mathrm{O}_{3}$ nanoparticles. Additionally, the morphology, topography and structure also affect the value of the refractive index of the synthesized nanoparticles. Figure 5 shows the extinction coefficient $K$ as a function of wavelength for $\mathrm{Al}_{2} \mathrm{O}_{3}$ nanoparticles synthesized at various laser fluences. The extinction coefficient was estimated from the absorption coefficient using the following equation: 

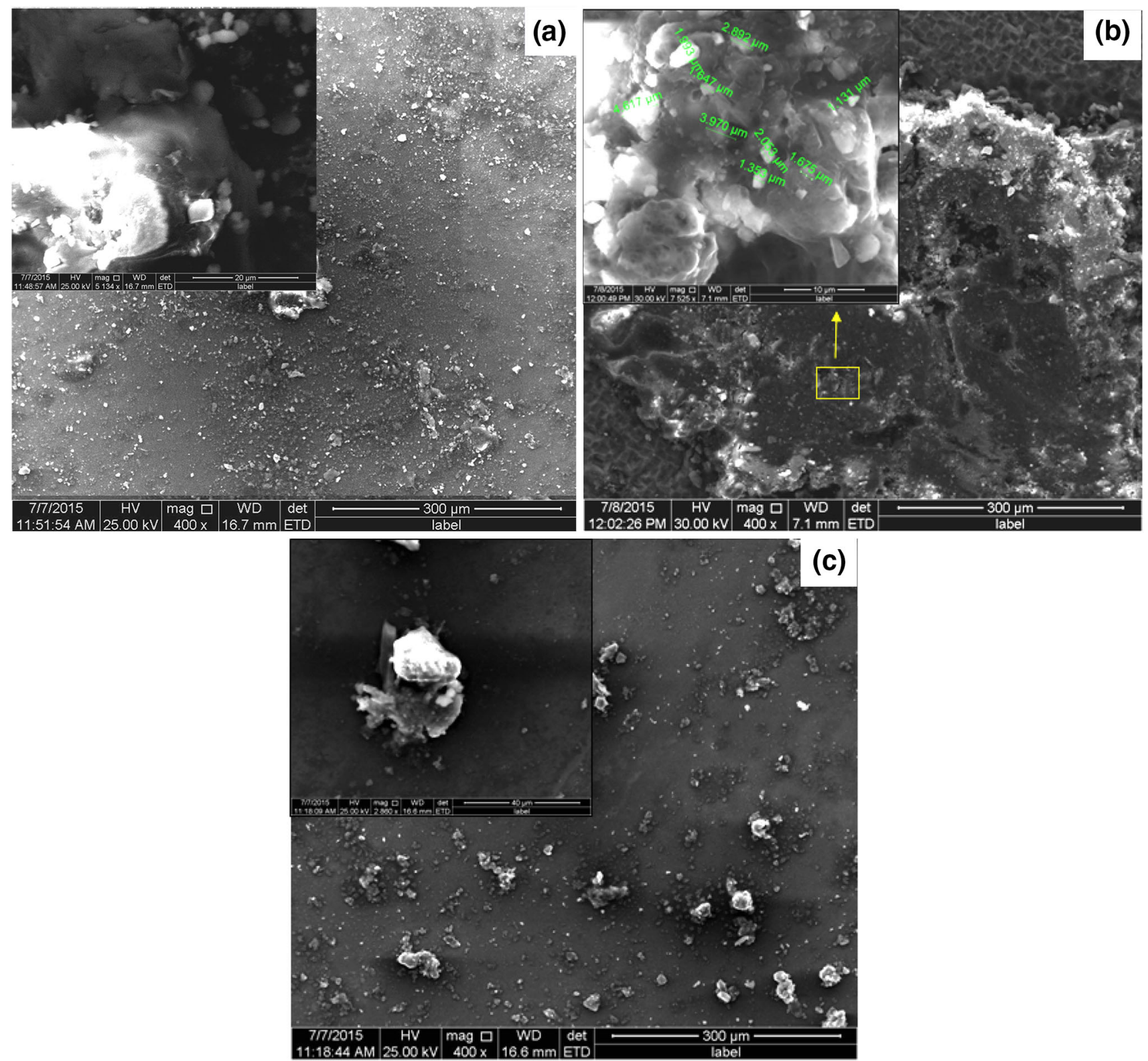

Fig. 6 SEM images of alumina nanoparticles synthesized at various laser fluences: a $3.5 \mathrm{~J} / \mathrm{cm}^{2}, \mathbf{b ~} 5.2 \mathrm{~J} / \mathrm{cm}^{2}$, c $7.3 \mathrm{~J} / \mathrm{cm}^{2}$. Inset shows the magnified SEM images

$K=\frac{\alpha \lambda}{4 \pi}$.

It is evident from Fig. 5 that the extinction coefficient decreases with laser wavelength and the sample prepared at higher laser fluence has maximum value of $K$. The extinction coefficient values at 270 and $500 \mathrm{~nm}$ for the sample prepared at laser fluence $3.5 \mathrm{~J} / \mathrm{cm}^{2}$ were 0.65 and 0.18 , respectively, while its values for $\mathrm{Al}_{2} \mathrm{O}_{3}$ synthesized at $5.2 \mathrm{~J} / \mathrm{cm}^{2}$ were 1.3 at $270 \mathrm{~nm}$ and 0.74 at $500 \mathrm{~nm}$.

This result can be ascribed to the increase of the particle size and the number of $\mathrm{Al}_{2} \mathrm{O}_{3}$ particles with laser fluence, which in turn increase the optical absorption (Tilaki et al. 2007). The
SEM images of $\mathrm{Al}_{2} \mathrm{O}_{3}$ nanoparticles are given in Fig. 6. It is evident from this figure that the morphology of alumina particles depends mainly on the laser fluence. Based on the particle morphology, the particles prepared at $3.5 \mathrm{~J} / \mathrm{cm}^{2}$ exhibit isolated and agglomerated particles with spherical and irregular shapes. The formed particles have different sizes ranging from $50 \mathrm{~nm}$ to sub-micrometers (inset of Fig. 6a). Increasing the laser fluence leads to the formation of micro-sized particles as well as agglomeration of particles as shown in Fig. $6(b, c)$. This finding can be ascribed to the mechanical stresses (shock wave) produced by the ablation the target with high laser intensity, which results in particle fragmentation (Ying-Hua et al. 2016). 
(a)

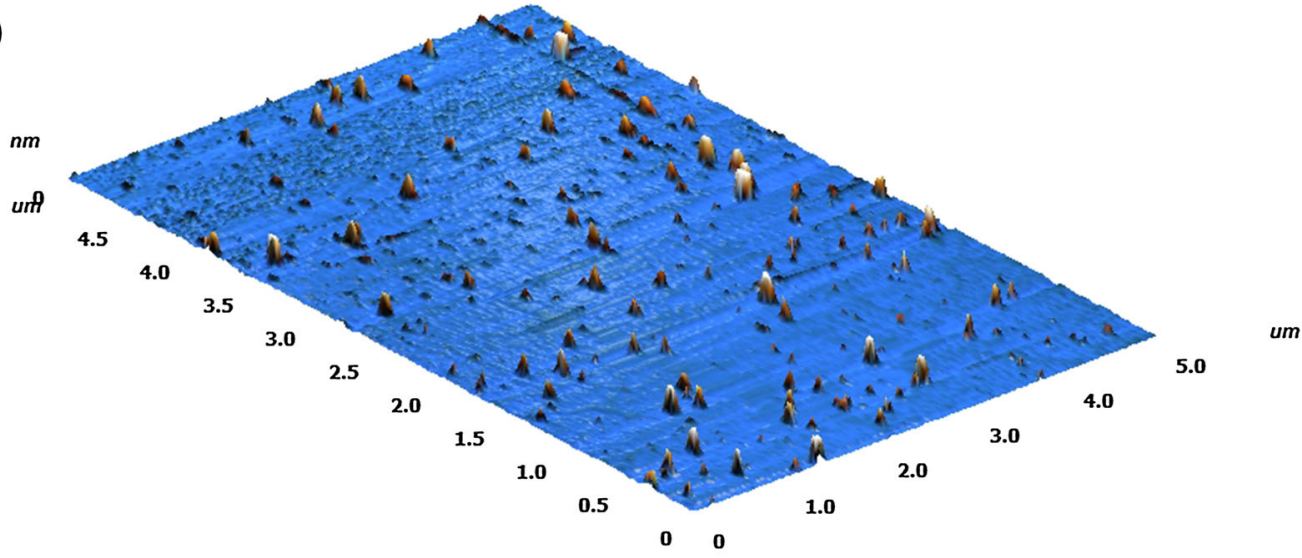

(b)

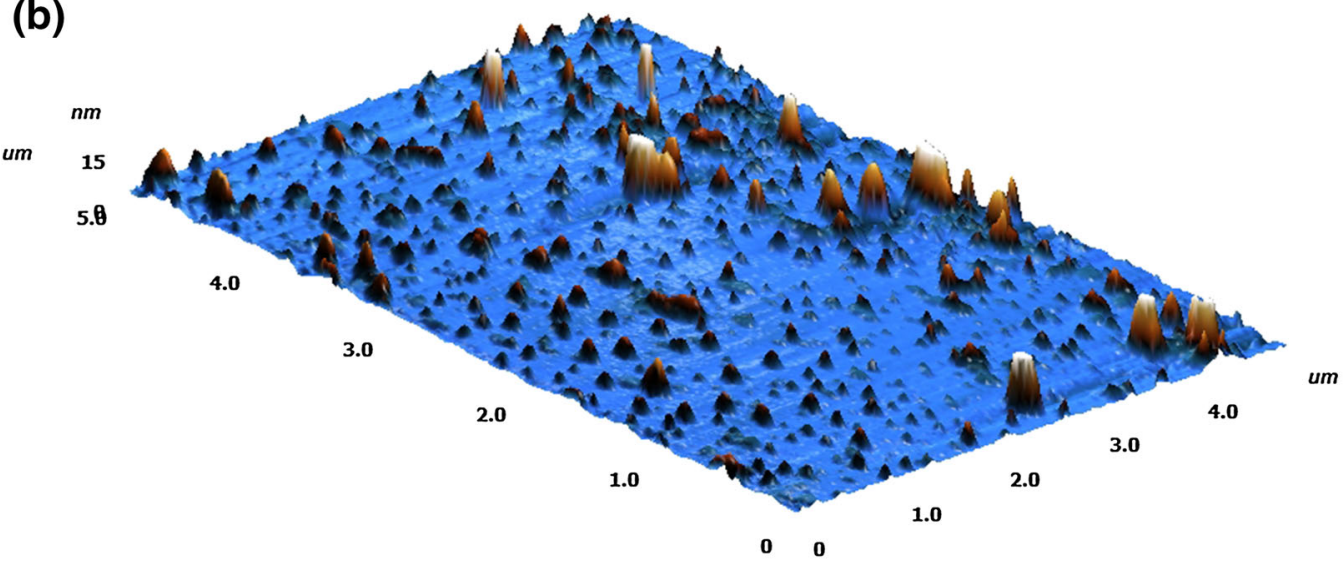

(c)

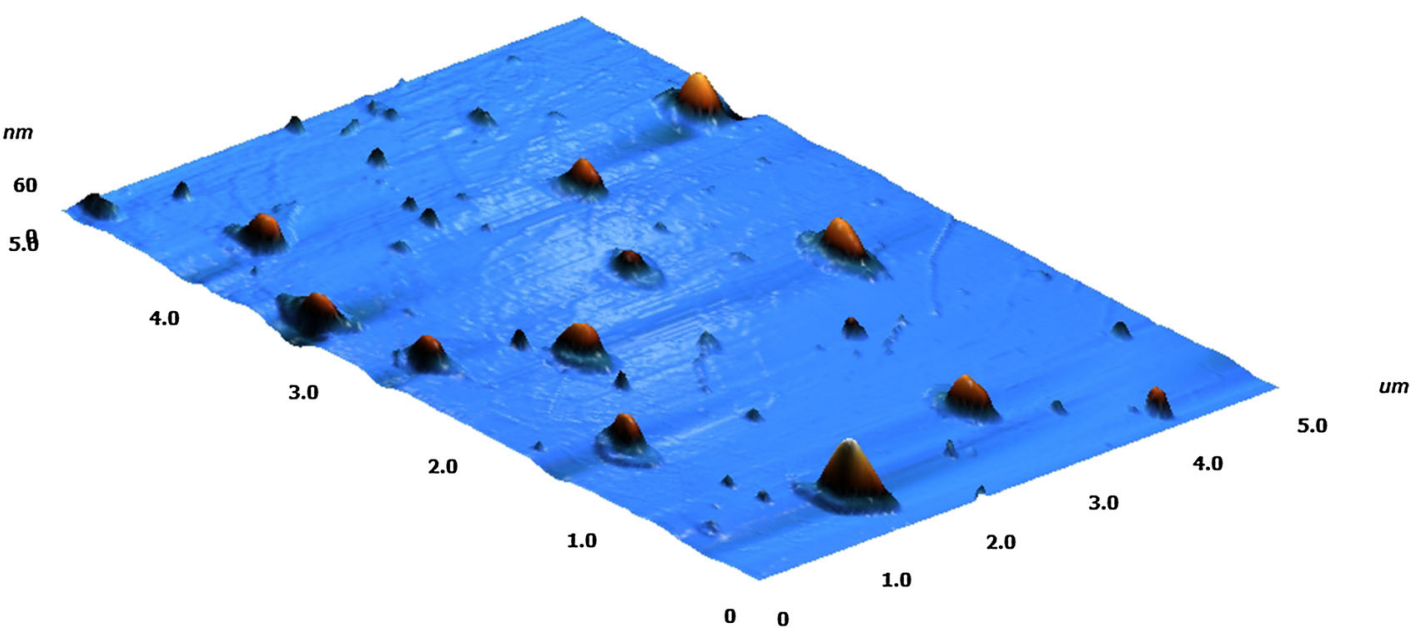

Fig. 7 3D AFM images of alumina nanoparticles prepared with various laser fluences: a $3.5 \mathrm{~J} / \mathrm{cm}^{2}, \mathbf{b ~} 5.2 \mathrm{~J} / \mathrm{cm}^{2}, \mathbf{c ~} 7.3 \mathrm{~J} / \mathrm{cm}^{2}$

The effect of laser fluence on the morphology of synthesized alumina nanoparticles was investigated with the aid of AFM. Figure 7 shows the 3D AFM images of $\mathrm{Al}_{2} \mathrm{O}_{3}$ nanoparticles prepared at various laser fluences. The particles are vertically oriented and their sizes depend on the laser fluence. The AFM of the alumina prepared at $3.5 \mathrm{~J} / \mathrm{cm}^{2} /$ pulse (Fig. 7a) showed different morphologies, and some of the particles have spherical shape as shown in 
(a)

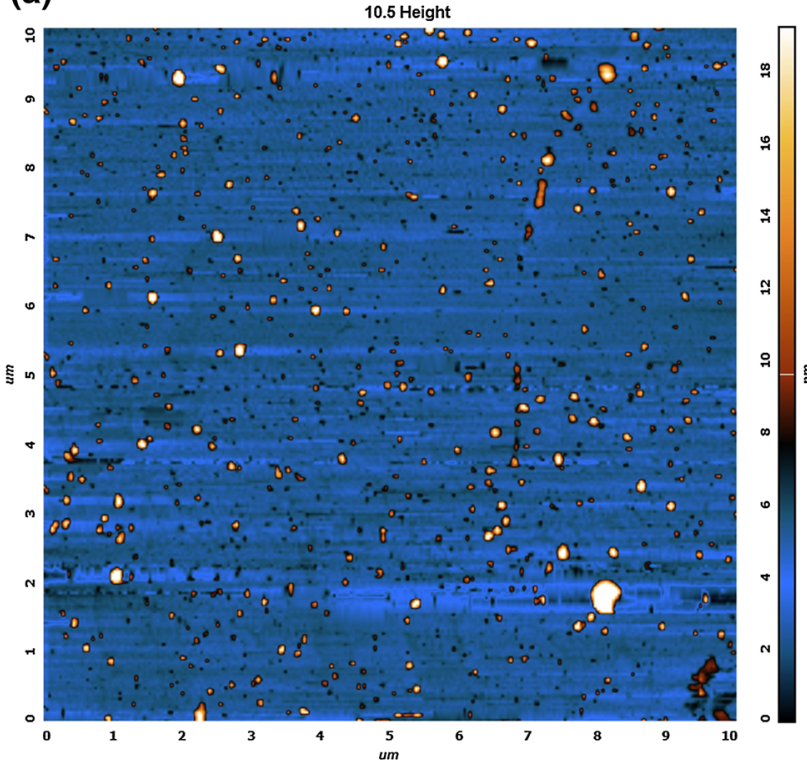

(b)

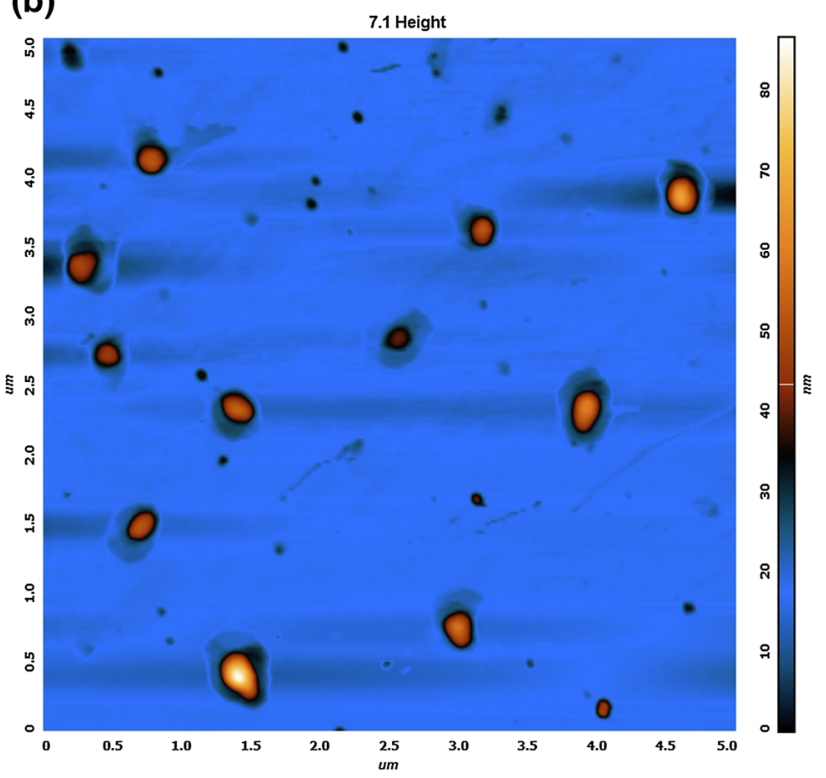

(c)

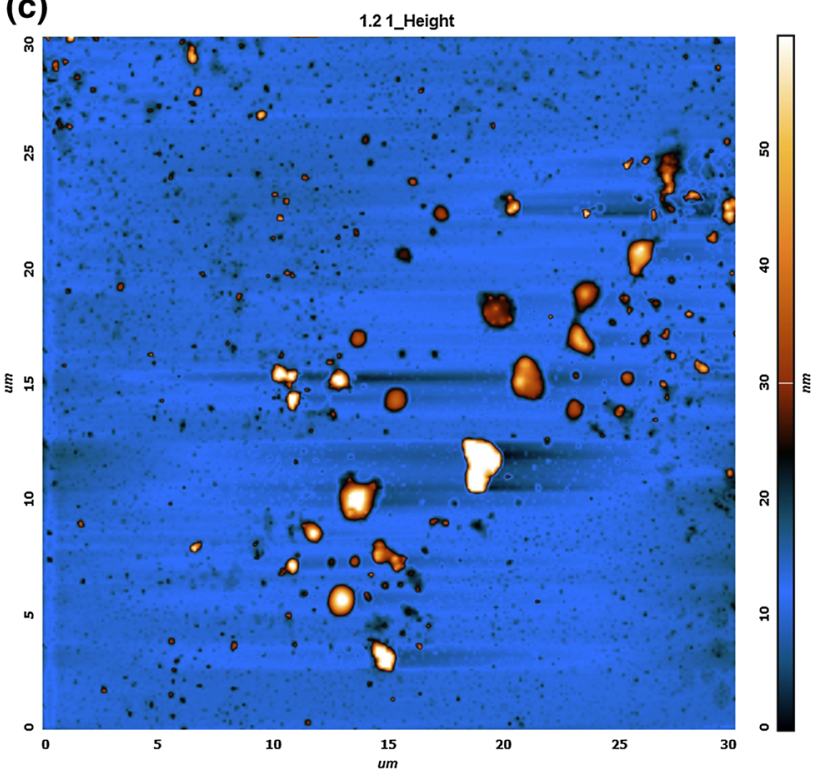

Fig. $82 \mathrm{D}$ AFM images of $\mathrm{Al}_{2} \mathrm{O}_{3}$ NPs synthesized at different laser fluences: a $3.5 \mathrm{~J} / \mathrm{cm}^{2}, \mathbf{b} 5.2 \mathrm{~J} / \mathrm{cm}^{2}, \mathbf{c} 7.3 \mathrm{~J} / \mathrm{cm}^{2}$

2D AFM image (Fig. 8a). The average grain size was estimated using software and it was around $55 \mathrm{~nm}$. Increasing the laser fluence leads to increasing the concentration of ablated alumina with larger size, while some of the small grains tend to agglomerate with each other to form larger grains (Fig. 7b, c). The alumina particles synthesized with high laser fluence have pyramid-like grains. The 2D AFM image confirms that these grains have non-spherical shape. The average grain sizes of alumina prepared at laser fluences of 5.2 and $7.3 \mathrm{~J} / \mathrm{cm}^{2} /$ pulse were 78 and $100 \mathrm{~nm}$, respectively. TEM was used to investigate the morphology, size and size distribution of the synthesized nanoparticles. Figure 9 shows the TEM images of alumina NPs prepared at various laser fluences and the insets are the particle size distribution determined by statistical analysis of the particles in images. The shape and size of the synthesized alumina particles are found to be greatly influenced by laser fluence. Alumina particles prepared with $3.5 \mathrm{~J} / \mathrm{cm}^{2} /$ pulse show monodispersed nanosized spherical particles and few particles agglomerated to form larger particles. The average particles size was estimated to be $\sim 60 \mathrm{~nm}$. Increasing the laser fluence leads to the formation of agglomerated and polydispersed nanoparticles, and the average particle size was 

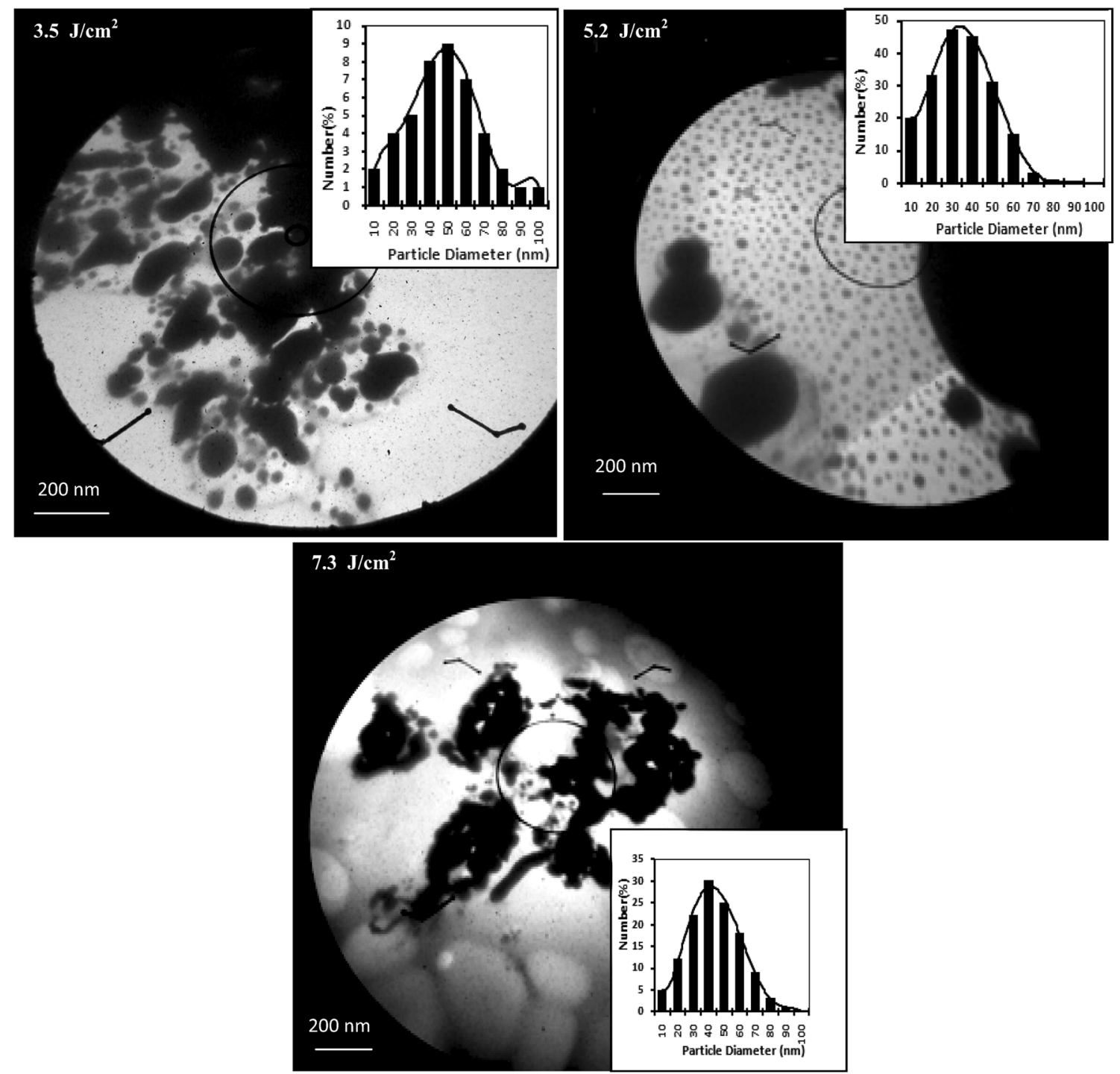

Fig. 9 TEM images of alumina NPs synthesized at various laser fluences. Inset shows the particle size distribution

approximately $85 \mathrm{~nm}$. A further increase in the laser fluence resulted in the formation of spherical and elongated alumina particles with an average size of $90 \mathrm{~nm}$. The values of particle size determined by TEM are close to those determined by AFM investigation. The particle size histograms confirm that the distribution of particles has a nearly Gaussian type of fitting, and the tail in the size distribution can be ascribed to the effect of agglomeration.

The optical reflectance spectra of 100 nm-thick $\mathrm{Al}_{2} \mathrm{O}_{3}$ film deposited on silicon photodiode at different laser fluences followed by RTA are shown in Fig. 10. In general, all the silicon surfaces gave lower optical reflectance after coating with nanostructured alumina film. The lowest reflectance of the silicon photodiode surface was noticed after deposition of the alumina layer prepared at $3.5 \mathrm{~J} / \mathrm{cm}^{2} /$ pulse. The average optical reflectance of silicon decreased from 31 to $15 \%$ after alumina deposition, indicating that the alumina layer works as an anti-reflection coating due to appropriate value of $n$ and very small value of $K$. Figure 10 shows also that the optical reflectivity of the $\mathrm{Al}_{2} \mathrm{O}_{3}$ layer increased after increasing the laser fluence. The data in Fig. 10 confirm the broadband reflectivity reduction over the whole 400-900 $\mathrm{nm}$ spectral range for all $\mathrm{Al}_{2} \mathrm{O}_{3}$ sample coating with respect to the silicon substrate.

The dark and illuminated current-voltage (I-V) characteristics of the photodiode after alumina deposition are illustrated in Fig. 11. The dark current $I_{\mathrm{d}}$ of the photodiode decreases and the photocurrent $I_{\mathrm{ph}}$ increases remarkably after deposition of the alumina films.

These results can be attributed to increase in the numbers of generating $\mathrm{e}-\mathrm{h}$ pairs after deposition of alumina, which resulted in increase in the photocurrent according to the following equation: 


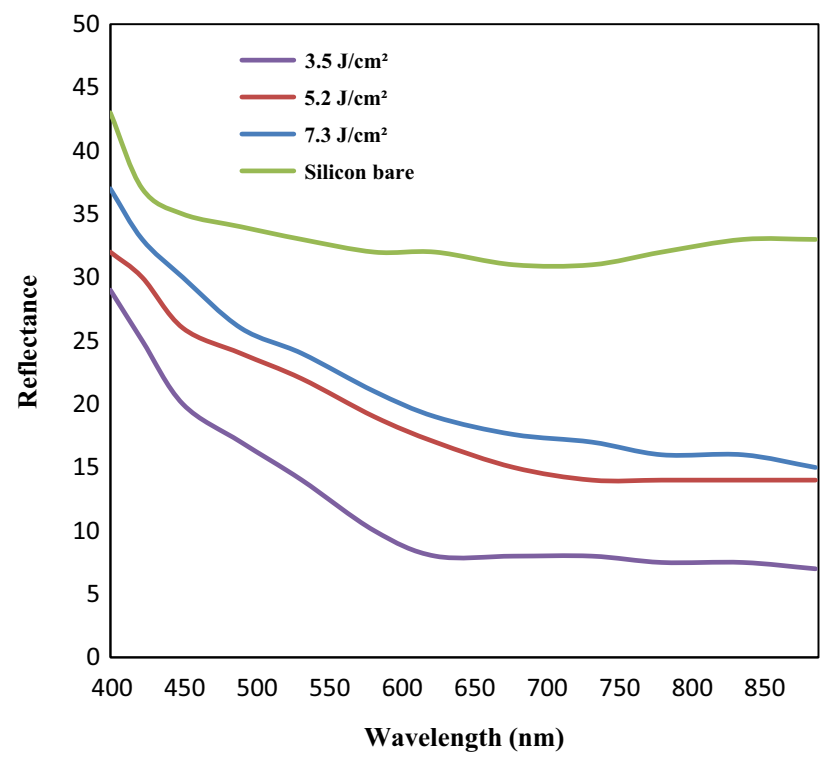

Fig. 10 Effect of laser fluence on the optical reflectance of nanostructured alumina films deposited on silicon photodiode

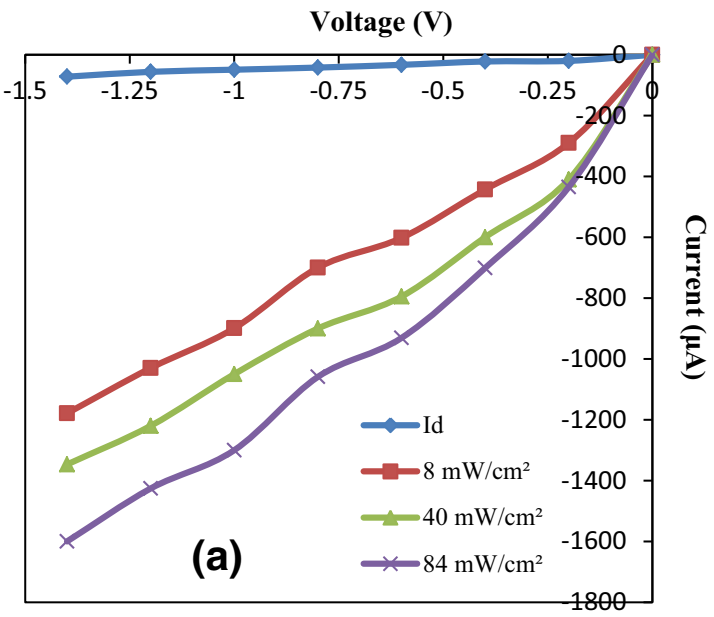

Voltage (V)

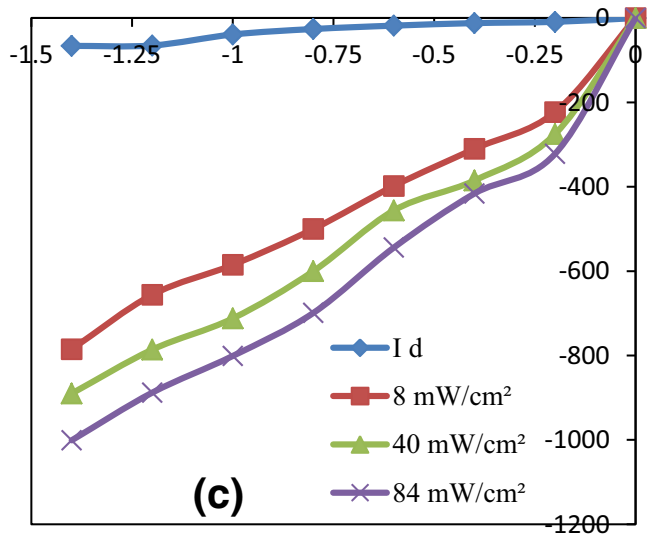

$I_{\mathrm{ph}}=(1-R) \frac{P \lambda \eta q}{h c}$,

where $P$ is the light power and $\eta$ the quantum efficiency of the photodiode. From the above equation, it is clear that the decrease in the reflectance of silicon photodiode leads to increase in its photocurrent. The maximum photocurrent was obtained for the photodiode-deposited alumina layer prepared at $3.5 \mathrm{~J} / \mathrm{cm}^{2} /$ pulse, and the photocurrent (illumination with $84 \mathrm{~mW} / \mathrm{cm}^{2}$ ) increased from 312 to $1600 \mu \mathrm{A}$ after deposition of the alumina coating. The second important parameter which plays a major role in increasing the photocurrent of the photodiode is the surface passivation arising from deposition of nanostructured alumina, followed by thermal annealing. The alumina is considered as an active source for supplying hydrogen to the silicon interface during the rapid thermal annealing process. Two possible surface passivation types can occur after the deposition of the alumina layer, the first one called chemical passivation and the second type called field-effect
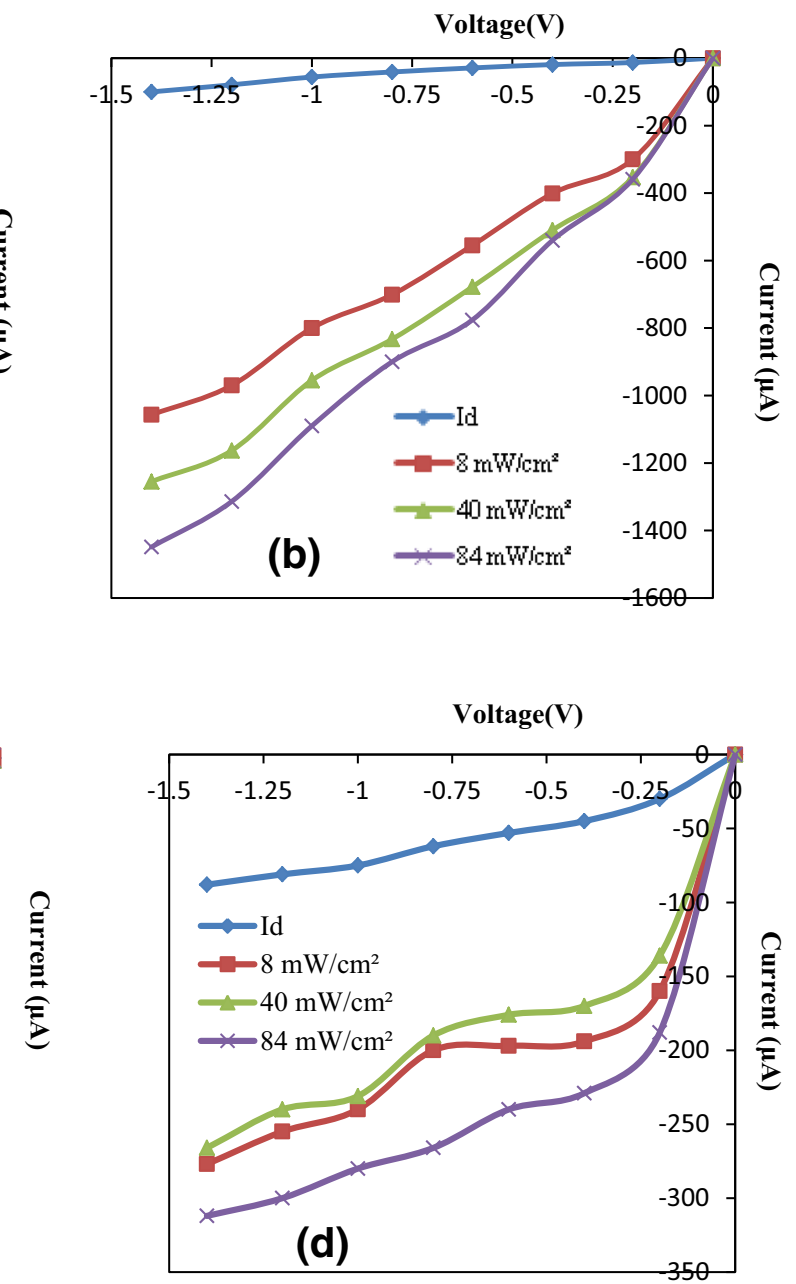

Fig. 11 Dark and illuminated I-V characteristics of the photodiode before alumina deposition (a) and after deposition of alumina prepared at different laser fluences: b $3.5 \mathrm{~J} / \mathrm{cm}^{2}$, c $5.2 \mathrm{~J} / \mathrm{cm}^{2}$, d $7.3 \mathrm{~J} / \mathrm{cm}^{2}$ 


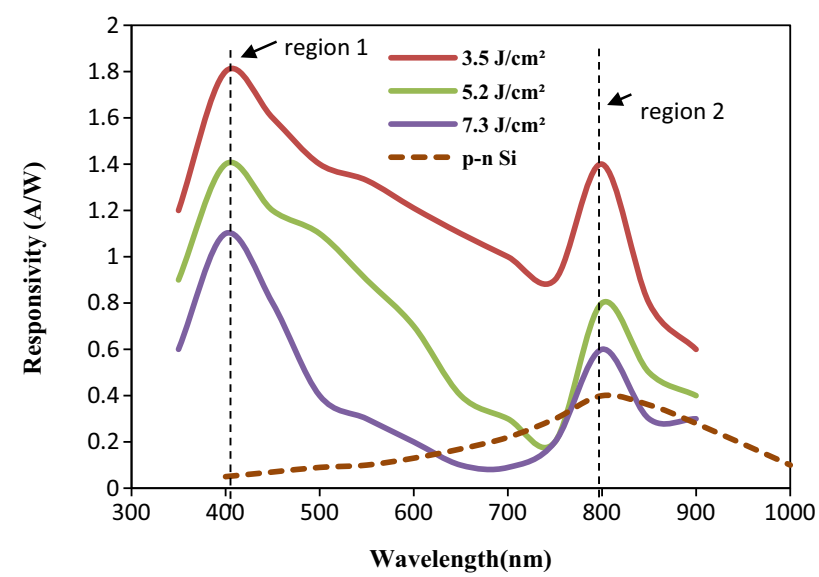

Fig. 12 Effect of alumina deposition and laser fluence on the responsivity of the silicon photodiode

passivation (Benjamin et al. 2012; Hoex et al. 2008; SaintCast et al. 2010; Terlinden et al. 2010). In the former type, the passivation resulted in decreasing the density of the surface states and dangling bonds existed on the silicon surface and enhanced the characteristics of the silicon photodiode, whereas the mechanism of passivation in the latter type based on decreasing the concentration of the minority charge carriers existed on the silicon surface. Increasing the laser fluence resulted in decreasing the photocurrent due to increasing of the surface reflectivity as well as due to agglomeration effect. Increase in the light intensity resulted in increasing the photocurrent due to more generation of $\mathrm{e}-\mathrm{h}$ pairs. Also, this figure confirms that the linearity characteristics were enhanced after the deposition of the $\mathrm{Al}_{2} \mathrm{O}_{3}$ layer. The deposition of nanostructured $\mathrm{Al}_{2} \mathrm{O}_{3}$ followed by RTA plays a positive role in the reduction of the series resistance of the photodiode through decreasing the surface state defect density (Ismail 2009). The improvement in the spectral responsivity of the photodiode (Fig. 12) is due to surface passivation and decrease of optical reflectance of the silicon photodiode after depositing nanostructured $\mathrm{Al}_{2} \mathrm{O}_{3}$. Furthermore, the alumina deposition increases the charger's carrier collection efficiency through formation of an inversion layer (Mikko et al. 2016). Two peaks of response were noticed in the spectral responsivity plot of all photodiodes after deposition of the $\mathrm{Al}_{2} \mathrm{O}_{3}$ layer as shown in Fig. 12. The first peak (region 1) was located at $410 \mathrm{~nm}$, indicating an enhancement in the detection of silicon photodiode in the visible region (visible-enhanced photodiode) and the second peak (region 2) was situated at $800 \mathrm{~nm}$ due to the absorption edge of the silicon.

It is clearly seen from Fig. 12 that the responsivity of the photodiode increases appreciably after alumina deposition from 0.4 to $1.4 \mathrm{AW}^{-1}$ at $800 \mathrm{~nm}$. This value is larger than that for wide band-gap silicon-based heterojunction photodetectors (Ismail et al. 2006; Ismail et al. 2005 , 2014). The photodiode deposited with alumina layer prepared at $3.5 \mathrm{~J} / \mathrm{cm}^{2} /$ pulse laser fluence exhibited the best sensitivity at the visible and near-infrared regions due to the effect of SPR. No significant variation in photodiode characteristics was observed after 2 months of storage in the laboratory.

\section{Conclusions}

In this work, we have successfully enhanced the photosensitivity of silicon photodiode throughout the deposition of crystalline $\mathrm{Al}_{2} \mathrm{O}_{3}$ nanoparticle layer on the p-layer of silicon photodiode prepared by laser ablation of $\mathrm{Al}$ target in ethanol. The deposited $\mathrm{Al}_{2} \mathrm{O}_{3}$ on silicon photodiode acts as an anti-reflection coating and surface passivation layer. The effect of laser ablation on the structural and optical properties of $\mathrm{Al}_{2} \mathrm{O}_{3} \mathrm{NPs}$ was investigated. The reflectivity of silicon photodiode was decreased after deposition of $\mathrm{Al}_{2} \mathrm{O}_{3}$; the lowest surface reflectance was noticed for silicon surface deposited with nanostructured alumina film prepared at a laser fluence of $3.5 \mathrm{~J} / \mathrm{cm}^{2} /$ pulse. Significant improvement in the photosensitivity of the photodiode was observed after deposition of the alumina layer. Two response peaks located at 400 and $800 \mathrm{~nm}$ were noticed after the deposition of the alumina film, and the responsivity at $800 \mathrm{~nm}$ was increased from 0.4 to $1.4 \mathrm{AW}^{-1}$ after deposition. Based on the obtained results, the technique used here to synthesize alumina nanoparticles is promising, cost-effective and encouraging for the development of visible-enhanced silicon photodiode.

Open Access This article is distributed under the terms of the Creative Commons Attribution 4.0 International License (http:// creativecommons.org/licenses/by/4.0/), which permits unrestricted use, distribution, and reproduction in any medium, provided you give appropriate credit to the original author(s) and the source, provide a link to the Creative Commons license, and indicate if changes were made.

\section{References}

Benjamin L, Jarmo S, Ville M, Shuo L, Sukgeun C, Howard B (2012) Excellent passivation and low-reflectivity $\mathrm{Al}_{2} \mathrm{O}_{3} / \mathrm{TiO}_{2}$ bilayer coatings for $n$-wafer silicon solar cells. In: IEEE photovoltaic specialists conference Austin, Texas, 3-8 June 2012, p 1

Cava S, Tebcherani S, Souza I, Pianaro S, Paskocimas C, Longo E (2007) Structural characterization of phase transition of $\mathrm{Al}_{2} \mathrm{O}_{3}$ nanopowders obtained by polymeric precursor method. J Varela Mater Chem Phys 103:394

Dingemans G, Kessels W (2012) Status and prospects of $\mathrm{Al}_{2} \mathrm{O}_{3}$-based surface passivation schemes for silicon solar cells. J Vac Sci Technol A 12:040802 
Emmanue S, Marios B, Costas F, Guillaume V, Cecile G, Georgy S (2009) Generation of Al nanoparticles via ablation of bulk Al in liquids with short laser pulses. Opt Express 17:12650

Farsi H, Gobal F (2007) Theoretical analysis of the performance of model supercapacitor consisting of metal oxide nano particles. J Solid State Electrochem 11:1085

Garces Y, Meyer D, Wheeler V, Liliental-Weber Z, Gaskill D, Eddy C, Vac J (2014) Plasma-assisted atomic layer deposition of nanolaminates for gate dielectric applications. Sci Technol B 32:03D101

Groner M, Fabreguette F, Elam J, George S (2004) Low-temperature $\mathrm{Al}_{2} \mathrm{O}_{3}$ atomic layer deposition. Chem Mater 15:639e45

Hart L (1990) Alumina chemicals: science and technology handbook. American Ceramic Society, Columbus

Hoex B, Schmidt J, Pohl P, Van de Sanden M, Kessels W (2008) Silicon surface passivation by atomic layer deposited $\mathrm{Al}_{2} \mathrm{O}_{3}$. J Appl Phys 104:044903

Hua B, Yaoa M, Xiaoa R, Chena J, Yao X (2014) Optical properties of amorphous $\mathrm{Al}_{2} \mathrm{O}_{3}$ thin films prepared by a sol-gel process. Ceram Int 40:14133

Huong N, Nagarajan B, Cheolmin P, Nguyen T, Anh L, Seunghwan L, Minhan J, Donhyun O, Vinh D, Junsin Y (2017) $\mathrm{Al}_{2} \mathrm{O}_{3} / \mathrm{SiON}$ stack layers for effective surface passivation and anti-reflection of high efficiency n-type c-Si solar cells. Semicond Sci Technol $32: 25005$

Ismail R (2009) Improved characteristics of sprayed CdO films by rapid thermal annealing. J Mater Sci 20:1219

Ismail R, Yahya K, Abdulrazaq O (2005) Preparation and photovoltaic properties of $\mathrm{Ag}_{2} \mathrm{O} / \mathrm{Si}$ isotype heterojunction. Surf Rev Lett 12:299

Ismail R, Raouf D, Raouf DF (2006) High efficiency $\operatorname{In}_{2} \mathrm{O}_{3} / \mathrm{c}-\mathrm{Si}$ heterojunction solar cells produced by rapid thermal oxidation. J Optoelectron Adv Mater 8:1443

Ismail R, Ghafori S, Kadhim G (2013) Preparation and characterization of nanostructured nickel oxide thin films by spray pyrolysis. Appl Nanosci 3:509

Ismail R, Al-Jawad S, Hussein N (2014) Preparation of $n-\mathrm{ZnO} / p-\mathrm{Si}$ solar cells by oxidation of zinc nanoparticles: effect of oxidation temperature on the photovoltaic properties. Appl Phys A 117:1977

Julien L, David A, Frederic C, Mouhamed D, Gilles L, Mary M, Karine V, Christophe D (2014) $\gamma-\mathrm{Al}_{2} \mathrm{O}_{3}$ nanoparticles synthesised by pulsed laser ablation in liquids: a plasma analysis. Phys Chem Chem Phys 16:963

Kavitha R, Jayaram V (2006) Deposition and characterization of alumina films produced by combustion flame pyrolysis. Surf Coat Technol 201:2491

Khan S, Liu Z, Li L (2010) Characteristics of $\gamma-\mathrm{Al}_{2} \mathrm{O}_{3}$ nanoparticles generated by continuous-wave laser ablation in liquid. Appl Phys A 101:781

Leszek A, Dobrzański S, Marek S, Aleksandra D (2014) Silicon solar cells with $\mathrm{Al}_{2} \mathrm{O}_{3}$ antireflection coating. S Magdal Cent Eur J Phys 12:666

Mikko J, Juha H, Ville V, Päivikki R, Dileep L, Hele S (2016) Nearunity quantum efficiency of broadband black silicon photodiodes with an induced junction. Nat Photonics 10:777

Mirjalili F, Hasmaliza M, Abdullah L (2010) Size-controlled synthesis of nano $\alpha$-alumina particles through the sol-gel method. Ceram Int 36:1253
Noda H, Muramoto K (2003) Preparation of nano-structured ceramics using nanosized $\mathrm{Al}_{2} \mathrm{O}_{3}$ particles. J Mater Sci 38:2043

Papi H, Jalali-Asadabadi S, Nourmohamma A, Ahmad I, Nematollahi J, Yazdanmehr M (2015) Optical properties of ideal $\gamma-\mathrm{Al}_{2} \mathrm{O}_{3}$ and with oxygen point defects: an abinitio study. RSC Adv 5:55088

Petersen S, Barcikowski S (2009) Conjugation efficiency of laserbased bioconjugation of gold nanoparticles with nucleic acids. J Phys Chem C 113(46): 19830

Piriyawong V, Thongpool V, Asanithi P, Limsuwan P (2012) Preparation and characterization of alumina nanoparticles in deionized water using laser ablation technique. J Nanomater 2012:819403

Qu L, He C, Yang Y, He Y, Liu Z (2005) Hydrothermal synthesis of alumina nanotubes templated by anionic surfactant. Mater Lett 59:4034

Reid C, Forrester J, Goodshaw H, Kisi E, Suaning G (2008) A study in the mechanical milling of alumina powder. Ceram Int 34:1551

Saint-Cast P, Benick J, Kania D, Weiss L, Hofmann M, Rentsch J, Preu R, Glunz S (2010) High-Efficiency c-Si solar cells passivated with ALD and PECVD aluminum oxide. IEEE Electron Device Lett 31:695

Shamala K, Murthy LCS, Narasimha Rao K (2004) Studies on optical and dielectric properties of $\mathrm{Al}_{2} \mathrm{O}_{3}$ thin films prepared by electron beam evaporation and spray pyrolysis method. Mater Sci Eng B 106:269-274

Tallarida M, Weisheit M, Kolanek K, Michling M, Engelmann H, Schmeißer D (2011) Atomic layer deposition of nanolaminate oxide films on Si. Nanoparticles Res 13:5975e83

Tamboli S, Puri V, Puri K, Patil R (2011) Comparative study of physical properties of vapor chopped and nonchopped $\mathrm{Al}_{2} \mathrm{O}_{3}$ thin films. M Luo 46:815

Tania C, Márcia G, Edilson B, João J (1999) Study of nanocrystalline $\gamma-\mathrm{al}_{2} \mathrm{O}_{3}$ produced by high-pressure compaction. J Phys Chem B 103:4278

Terlinden N, Dingemans G, van de Sanden M, Kessels W (2010) Role of field-effect on c-Sic-Si surface passivation by ultrathin (2-20 nm) atomic layer deposited $\mathrm{Al}_{2} \mathrm{O}_{3}$. Appl Phys Lett 96:112101

Tilaki R, Zad I, Mahdavi S (2007) Size, composition and optical properties of copper nanoparticles prepared by laser ablation in liquids. Appl Phys A 88:415-419

Trinh D, Ottosson M, Collin M, Reineck I, Hultman L, Ḧogberg H (2008) Nanocomposite $\mathrm{Al}_{2} \mathrm{O}_{3}-\mathrm{ZrO}_{2}$ thin films grown by reactive dual radio-frequency magnetron sputtering. Thin Solid Films 516:4977

Wooten F (1972) Optical properties of solids. Academic Press, New York

Yang L, May PW, Yin L, Smith JA, Rosser KN (2007) Ultra fine carbon nitride nanocrystals synthesized by laser ablation in liquid solution. J Nanoparticles Res 96:1181

Yatsui K, Yukawa T, Grigoriu C, Hirai M, Jiang W (2000) Synthesis of ultrafine $\gamma-\mathrm{Al}_{2} \mathrm{O}_{3}$ powders by pulsed laser ablation. J Nanoparticle Res 2:75

Ying-Hua L, Yu Zhao L, Xue-Mei Z, Zu-Gen Y, Xiang-Ping Z, Jie C, Ling-Cang Z Lin (2016) In situ measurement of the particle size distribution of the fragmentation product of laser-shock-melted aluminum using in-line picosecond holography. AIP Adv 6:025208 